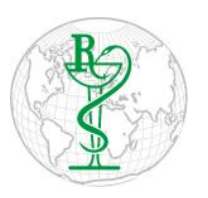

INDO GLOBAL JOURNAL OF

PHARMACEUTICAL SCIENCES

ISSN 2249- 1023

\title{
In Vitro Antioxidant, Anti-arthritic, and Anti-Cancer Activities of Cissus quadrangularis Stem Extract
}

\author{
B. Packialakshmi *, S. Makesh \\ Department of Biochemistry, PSG College of Arts and Science, Affiliated to Bharathiar University, Coimbatore - 641014, Tamilnadu, India
}

Address for Correspondence: B. Packialakshmi, biochem_bagya@yahoo.co.in

Received:

05.05.2019

Accepted:

24.12.2019

Published:

03.11.2020

\section{Keywords}

Anti-cancer,

Anti-

inflammatory,

Antioxidants,

Cissus

quadrangularis,

Free radicals,

Osteosarcoma.
ABSTRACT: Cissus quadrangularis is traditionally used for the treatment of several inflammatory disorders such as rheumatisms, wounds and tumours. In this study, the antioxidant, anti-inflammatory and anticancer activities of methanolic extract from the stem of Cissus quadrangularis (CQME) were evaluated in vitro. Five different solvents with different polarities (ethanol, methanol, ethyl acetate, petroleum ether and distilled water) were used to extract different compounds from the stem of $C$. quadrangularis. Fouriertransform infrared (FT-IR) spectroscopy was performed to analyse the presence of functional groups. Antioxidant activity of CQME was determined by measuring hydrogen peroxide (H2O2) radical scavenging activities. The anti-inflammatory activity was studied using the inhibition of protein (BSA) denaturation assay and the cytotoxic effects of CQME on MG63 cell lines were determined by MTT assay. Phytochemical screening of CQME confirmed the presence of phytochemicals such as phenols, carbohydrates, proteins, alkaloids, flavonoids, triterpenoids, saponins and steroids. The FT-IR spectral analysis revealed different characteristic peak values with various functional compounds in CQME and it was shown to be excellent scavenger of $\mathrm{H}_{2} \mathrm{O}_{2}$ radical. CQME exhibited significant dose-dependent anti-arthritic activity with the $\mathrm{IC}_{50}$ value of $170.78 \mu \mathrm{g} / \mathrm{mL}$. Moreover, CQME displayed strong antiproliferative potential against MG63 cell line and the IC50 was found to be $17.5 \mu \mathrm{g} / \mathrm{mL}$. Thus from the present investigation, it could be inferred that CQME exerted significant antioxidant, antiarthritic and anticancer effects. $C$. quadrangularis has a promising potential to be used as a drug source for inflammation and cancer treatment. () 2020 iGlobal Research and Publishing Foundation. All rights reserved.

Cite this article as: Packialakshmi, B.; Makesh, S. In vitro antioxidant, anti-arthritic and anti-cancer activities of Cissus quadrangularis stem extract. Indo Global J. Pharm. Sci., 2020; 10(1): 50-56. DOI: http://doi.org/10.35652/IGJPS.2020.10107.

\section{INTRODUCTION}

Medicines derived from plants are very popular due to their safety, low cost and easy availability [1]. Herbal medicines may include whole plant or any parts of plant such as leaves, roots, bark, seeds and flowers [2, 3]. The bioactive phytochemical constituents are responsible for the medicinal value of these plants. Some of the most important phytochemicals are phenolic compounds, alkaloids, flavonoids, tannins, terpenoids, essential oils, saponins and many more. During past several years, there has been a growing interest among the usage of different medicinal plants as a medicine for the treatment of different diseases [4]. Different kinds of herbal plants have been used for years to treat various diseases all over the world. Sometimes, synthetic drugs may cause some side effects and development of other disorders. To overcome these problems, nowadays, herbals are used as a source of medicine to treat various disorders $[5,6]$.

Cissus quadrangularis is a perennial plant belongs to grape family. It is commonly known as devil's backbone, veldt grape, adamant creeper, pirandai, asthisamharaka and hadjod [7]. It is native to tropical Asia, Africa and Arabia. It has been used in traditional medicines to heal bone injury. In siddha medicine, it is considered as a analgesic and tonic. The Assamese people and the Garo tribe of Meghalaya and Bangladesh are using these herbs for bone fracture [8]. It has 


\section{Indo Global Journal of Pharmaceutical Sciences, 2020; 10(1): 50-56}

been used to cure ailments such as allergies, asthma, diabetes, gout, cancer, heart disease, high cholesterol, osteopenia, osteoporosis and malaria [9].

Pharmacological studies reveal that various functional and nutritional phytochemicals have been extracted from this plant. These phytochemicals act as antioxidants by neutralizing free radicals which damage DNA, proteins and lipids [10]. These bioactive substances act as natural anticancer agents and have been used to treat many kinds of cancers such as breast, lung, colon, and liver cancer [11]. However, the anticancer effects of $C$. quadrangularis stem extracts on human osteosarcoma have not been studied so far. Therefore, in the present study, we analysed the presence of phytochemicals in different solvent extracts of $C$. quadrangularis stem. This study was also focused on investigating its antioxidant, anti-arthritic potential and anti-cancer activity on human osteosarcoma MG63 cells.

\section{MATERIALS AND METHODS}

\section{Collection of plant material}

The fresh and healthy stems of $C$. quadrangularis were collected in the month of December 2018 to January 2019 from the areas in and around the villages of Coimbatore, Tamil Nadu.

\section{Preparation of extracts}

The collected stem of $C$. quadrangularis were shade dried, powered and extracted in a Soxlet extractor using different solvents such as ethanol (CQEE), methanol (CQME), ethyl acetate (CQEAE), petroleum ether (CQPEE) and distilled water (CQAE). The extracts were collected under reduced pressure to get semi solid mass and stored at $-20^{\circ} \mathrm{C}$ for further use.

\section{Cell lines and Culture medium}

MG63 (Human Osteosarcoma cell) was procured from National centre for cell sciences (NCCS), Pune, India. Stock cells were cultured in MEM supplemented with $10 \%$ inactivated fetal bovine serum (FBS), penicillin (100 $\mathrm{IU} / \mathrm{ml})$, streptomycin $(100 \mu \mathrm{g} / \mathrm{ml})$ and amphotericin B (5 $\mu \mathrm{g} / \mathrm{mL})$ in a humidified atmosphere of $5 \% \mathrm{CO}_{2}$ at $37^{\circ} \mathrm{C}$ until confluent. The cells were dissociated with TPVG solution $(0.2 \%$ trypsin, $0.02 \%$ EDTA, $0.05 \%$ glucose in PBS). The stock cultures were grown in $25 \mathrm{~cm}^{2}$ culture flasks and all experiments were carried out in 96 microtitre plates (Tarsons India Pvt. Ltd., Kolkata, India).

\section{Chemicals}

EDTA, glucose and antibiotics from Hi-Media laboratories Ltd., Mumbai. Dimethyl sulfoxide (DMSO) and propanol from E. Merck Ltd., Mumbai, India. 3-(4,5-dimethyl thiazol2-yl)-5-diphenyl tetrazolium bromide (MTT), fetal bovine serum (FBS), Phosphate buffered saline (PBS), MEM medium, trypsin and other chemicals were purchased from Sigma-Aldrich (Bangalore, India).

\section{Qualitative analysis of phytochemicals}

For preliminary phytochemical analysis, standard procedures were performed in different extracts of $C$. quadrangularis. Phytoconstituents such as phenols, carbohydrates, proteins, glycosides, alkaloids, flavonoids, triterpenoids, saponins and steroids were examined by performing different phytochemical tests [12].

\section{FT-IR spectral analysis}

The FT-IR spectrum of CQME was recorded with a FT- IR spectrometer (IR-affinity 1, Sigma, Japan) using $\mathrm{KBr}$ pellet method [13]. The dried extract was grounded with $\mathrm{KBr}$ powder and then pressed into $1 \mathrm{~mm}$ pellets for FT-IR measurement from 4000 to $400 \mathrm{~cm}^{-1}$.

\section{Estimation of total phenolic content}

The total phenol in CQME was measured according to the method of Singleton and Rossi [14] with some modifications. $1.0 \mathrm{~mL}$ of the sample was mixed with $1.0 \mathrm{~mL}$ of Folin-Ciocalteu's phenol reagent and after 3 min, $1.0 \mathrm{~mL}$ of saturated sodium carbonate $(35 \%)$ was added to the mixture. The mixture was made up to 10 $\mathrm{mL}$ by adding deionised water and kept for $90 \mathrm{~min}$ at room temperature in the dark. The absorbance was measured immediately against the prepared blank at $725 \mathrm{~nm}$. Ferulic acid was used as the reference standard. The total phenol content is expressed as milligrams of ferulic acid equivalents (FAE) per gram of extract.

\section{Estimation of total flavonoid content}

Total flavonoid content in CQME was evaluated as described by Jia et al [15]. $0.25 \mathrm{~mL}$ of sample was diluted with $1.25 \mathrm{~mL}$ of distilled water and $75 \mu \mathrm{L}$ of a $5 \%$ sodium nitrite were added. After $6 \mathrm{~min}, 150 \mu \mathrm{L}$ of a $10 \%$ aluminium chloride was added and mixed. $0.5 \mathrm{~mL}$ of $1 \mathrm{M}$ sodium hydroxide was added after $5 \mathrm{~min}$. The absorbance was measured at $510 \mathrm{~nm}$ against the blank. Quercetin was used as the reference standard. The total 


\section{Indo Global Journal of Pharmaceutical Sciences, 2020; 10(1): 50-56}

flavonoid content is expressed as milligrams of quercetin equivalents (QE) per gram of extract.

\section{Hydrogen peroxide scavenging activity assay}

The scavenging activity of CQME on hydrogen peroxide $\left(\mathrm{H}_{2} \mathrm{O}_{2}\right)$ radicals was measured according to the method of Ruch et al [16]. Extract with different concentrations were added to $3.4 \mathrm{~mL}$ of $0.1 \mathrm{M}$ phosphate buffer solution ( $\mathrm{pH} 7.4$ ). $600 \mu \mathrm{L}$ of $43 \mathrm{mM} \mathrm{H} \mathrm{H}_{2} \mathrm{O}_{2}$ was added gently to the above mixture. $\mathrm{H}_{2} \mathrm{O}_{2}$ concentration was measured at $230 \mathrm{~nm}$ after 10 min. Ascorbic acid was used as a reference compound.

\section{In vitro anti-arthritic activity}

\section{Inhibition of albumin denaturation}

CQME $(0.05 \mathrm{~mL})$ at various concentrations $(50,100,150$, 200 and $250 \mu \mathrm{g} / \mathrm{mL}$ ) and standard drug, diclofenac sodium $(0.05 \mathrm{~mL})$ at different concentrations $(50,100,150,200$ and $250 \mu \mathrm{g} / \mathrm{mL})$ were taken separately and $0.45 \mathrm{~mL}$ of BSA $(0.5 \%$ w/V BSA) was added to both test and standard drug solution. Test control solution consisted of $0.05 \mathrm{~mL}$ of distilled water and $0.45 \mathrm{~mL}$ of BSA. The samples were incubated at $37^{\circ} \mathrm{C}$ for $20 \mathrm{~min}$ and the temperature was increased progressively up to $57^{\circ} \mathrm{C}$ for $3 \mathrm{~min}$. After cooling, add $2.5 \mathrm{~mL}$ of phosphate buffer to the above solutions after $20 \mathrm{~min}$. The absorbance was measured using UV-Visible spectrophotometer at $416 \mathrm{~nm}$ [17]. The results were compared with the standard drug, diclofenac sodium. The percentage inhibition of protein denaturation can be calculated as.

Percentage Inhibition $=100-[\{($ Absorbance of test solution Absorbance of standard drug solution) / Absorbance of test control solution $\} / \times 100]$.

\section{In vitro anti-cancer activity}

The antiproliferative activity of CQME was measured using the 3-(4,5-dimethylthiazol-2-yl)-2,5-diphenyltetrazolium bromide (MTT assay; Sigma, USA). The monolayer cell culture was trypsinized and the cell count was adjusted to 1.0 x 105 cells/ml using MEM containing 10\% FBS. To each well of the 96 well microtitre plate, $0.1 \mathrm{~mL}$ of the diluted cell suspension (approximately 10,000 cells) was added. After 24 $\mathrm{h}$, when a partial monolayer was formed, the supernatant was flicked off, washed the monolayer once with medium and $100 \mu \mathrm{L}$ of different test concentrations of test drug was added on to the partial monolayer in microtitre plates. The plates were then incubated at $37^{\circ} \mathrm{C}$ for 3 days in $5 \% \mathrm{CO}_{2}$ atmosphere, and microscopic examination was carried out and observations were noted every $24 \mathrm{~h}$ interval. After $72 \mathrm{~h}$, the drug solutions in the wells were discarded and $50 \mu \mathrm{l}$ of MTT in PBS was added to each well. The plates were gently shaken and incubated for $3 \mathrm{~h}$ at $37^{\circ} \mathrm{C}$ in $5 \% \mathrm{CO}_{2}$ atmosphere. The supernatant was removed and $100 \mu \mathrm{L}$ of propanol was added and the plates were gently shaken to solubilize the formed formazan. The number of cells was found to be proportional to the extent of formazan production by the cells used The absorbance was measured using a microplate reader at a wavelength of $540 \mathrm{~nm}$ [18].

\section{Statistical analysis}

All biochemical analyses were carried out in triplicates and the results are expressed as mean $\pm \mathrm{SD}$. Collected data were subjected to statistical analysis using Analysis of variance (ANOVA) and Duncan's multiple range test (DMRT) with least significance difference (LSD), $\mathrm{P}$ $<0.05$ as a level of significance. The data were analyzed using SPSS software.

\section{RESULTS AND DISCUSSION}

\section{Phytochemical analysis}

The beneficial medicinal effect of plant materials typically results from combination of secondary metabolites present in plants [19]. These compounds include alkaloids, tannin, phenols, flavonoids, resins, gums which are capable of producing definite physiology action on the body [20]. Phytochemical screening is very important in identifying new source of industrially and therapeutically valuable compound with medicinal significance [21].

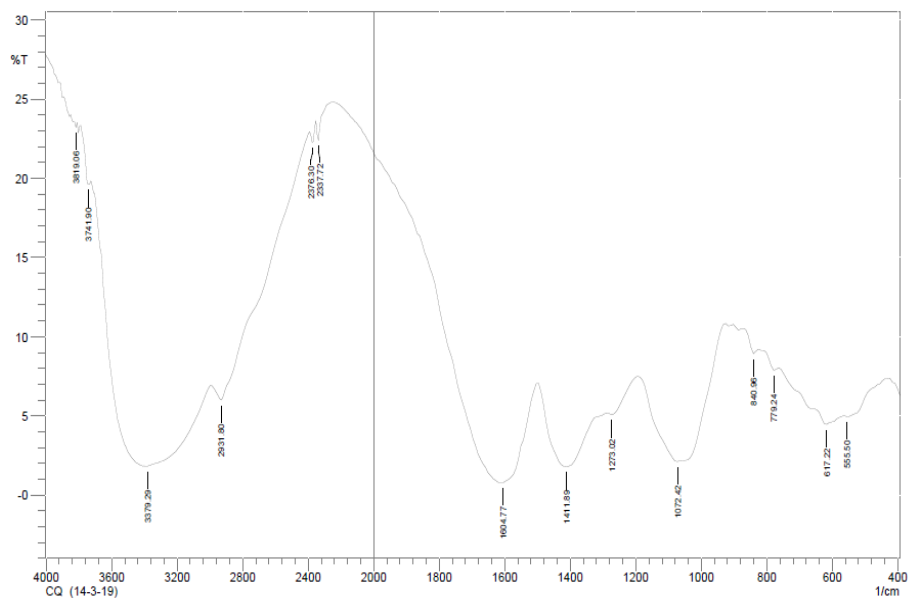

Figure 1: FT-IR of CQME

The phytochemical analysis was carried out in CQEE, CQME, CQEAE, CQPEE and CQAE extracts to find out the existence of certain phytoconstituents such as phenols, carbohydrates, proteins, glycosides, alkaloids, flavonoids, triterpenoids, saponins and steroids and the results were shown in Table 1. CQEE showed the presence of proteins, flavonoids, saponins and steroids. Phenols, carbohydrates, proteins, alkaloids, flavonoids, triterpenoids, saponins and steroids were present in CQME. CQEAE showed the 
Indo Global Journal of Pharmaceutical Sciences, 2020; 10(1): 50-56

presence of phenols, alkaloids and saponins. Alkaloids, flavonoids and steroids were present in CQPEE. CQAE showed the presence of phenols, carbohydrates, proteins and saponins. CQME was found to contain more phytochemical constituents compared to other extracts. Thus further studies were performed on CQME.

\section{Fourier-transform infrared (FT-IR) spectroscopy}

FT-IR spectrum was performed in order to investigate the molecular properties of CQME (Figure 1). The large variety of functional groups (hydroxyl groups, acids, esters, amide I and amide II, aliphatic chains of fatty acids and acidic amino acids) makes the CQME spectra very complex. The absorption peaks corresponded to different and specific wave number ranges, e.g. 3819-3000 $\mathrm{cm}^{-1}$ for $\mathrm{O}-\mathrm{H}$ stretching modes of water absorbing, the $\mathrm{C}-\mathrm{H}$ stretching vibrations in fatty acids (3000-2800 $\left.\mathrm{cm}^{-1}\right)$, the stretching of $\mathrm{C}=\mathrm{O}$ bonds in acids and esters $\left(1750-1650 \mathrm{~cm}^{-1}\right)$, the amide I and amide II IR absorptions of proteins (1650-1450 $\left.\mathrm{cm}^{-1}\right)$, esters and aliphatic chains of fatty acids (1411 $\left.\mathrm{cm}^{-1}\right)$ and $\mathrm{C}=\mathrm{O}$ and $\mathrm{C}-\mathrm{C}$ stretching of acids $(1200-800$ $\mathrm{cm}^{-1}$ ), as reported by other authors [22].

A very intense peak at $3379 \mathrm{~cm}^{-1}$ was due to the stretching of $\mathrm{N}-\mathrm{H}$ (aliphatic primary amine). The strong absorption peak at $2376 \& 2337 \mathrm{~cm}^{-1}$ was due to the stretching vibration of $\mathrm{O}=\mathrm{C}=\mathrm{O}$ [23]. The absorption peak near $1604 \mathrm{~cm}^{-1}$ was for Quinone or conjugated ketone $(\mathrm{C}=\mathrm{O}$ stretching $)$. The very intense peak at $1072 \mathrm{~cm}^{-1}$ indicated $\mathrm{C}-\mathrm{N}$ stretching (primary amines). The absorption peak near $840 \mathrm{~cm}^{-1}$ was for hydrogen-bonded $\mathrm{O}-\mathrm{H}$ out-of-plane bending. The signal at $779 \mathrm{~cm}^{-1}$ was an indicative of skeletal C-C vibrations. The very intense peak at $1273 \mathrm{~cm}^{-1}$ indicated $\mathrm{C}-\mathrm{N}$ stretching (primary amines). The absorption peak near $500 \mathrm{~cm}^{-1}$ to $600 \mathrm{~cm}^{-1}$ was for C-I stretching [24].

\section{Quantification of phytochemical components}

Phenolics are considered as very important phytochemical for their antioxidant activity due to their ability to scavenge free radicals [25]. Phenolics and flavonoids of plants reduce the risk of degenerative diseases associated with free radical damage. Flavonoids and phenols play important role in preventing cancer development [26]. Table 2 represents the total phenols and flavonoid content of CQME. The total phenolic and flavonoid contents were found to be 10.25 $\mathrm{mg}$ FAE/g extract and $5.36 \mathrm{mg}$ QE/g extract respectively. Flavonoids showed a wide range of anticancer, antibacterial, anti-inflammatory and antiviral activities in several studies [27].

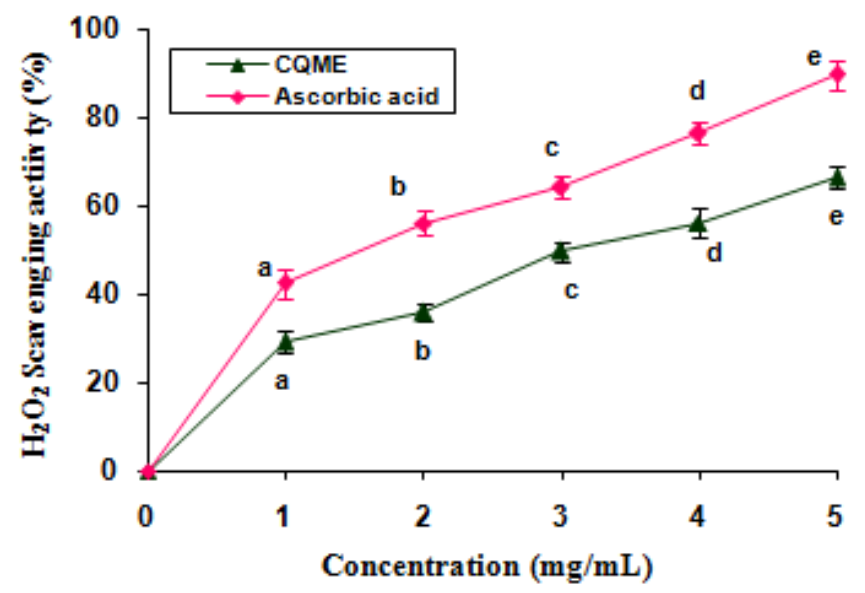

Figure 2: $\mathrm{H}_{2} \mathrm{O}_{2}$ radical scavenging activity of CQME. [CQME = Cissus quadrangularis methanol extract; Values are expressed as mean $\pm S D(n=3)$. Different letters (a-e) indicate a significant difference between the concentrations of the same extract $(P<0.05$, ANOVA, DMRT)].

\section{In vitro antioxidant activity $\mathrm{H}_{2} \mathrm{O}_{2}$ scavenging assay}

Free radicals play a vital role in the progression of many diseases [28]. Initiation of lipid peroxidation that causes DNA damage is due to the creation of hydroxyl radicals $(\bullet \mathrm{OH})$ by $\mathrm{H}_{2} \mathrm{O}_{2}$ decomposition. High concentration of hydroxyl radicals in the tissue is very toxic and may initiate cancer development [29]. The scavenging effect of CQME on $\mathrm{H}_{2} \mathrm{O}_{2}$ is shown in Figure 2. At concentrations of $1-5 \mathrm{mg} / \mathrm{mL}$, the scavenging abilities were between $29.34 \%-66.61 \%$ for CQME and 42.53 $\%-89.74 \%$ for ascorbic acid. The standard drug, ascorbic acid $\left(\mathrm{EC}_{50}=2.19 \mathrm{mg} / \mathrm{mL}\right)$ exhibited significantly $(\mathrm{P}<0.05)$ high $\mathrm{H}_{2} \mathrm{O}_{2}$ scavenging potential when compared with CQME $\left(\mathrm{EC}_{50}\right.$ $=3.35 \mathrm{mg} / \mathrm{mL}$ ). The phytochemicals present in the medicinal plants have the ability to reduce hydroxyl radical formation, and its deleterious effects in body systems [30].

Effect of CQME on protein denaturation using bovine serum albumin

Protein denaturation is one of the main causes of inflammatory diseases, which leads to the production of auto antigens and development of rheumatic diseases. The mechanism involved in protein denaturation is characterized by alterations in electrostatic, hydrophobic, disulphide and hydrogen bonding among the protein molecules. Substances that can prevent protein denaturation would be very important for antiarthritic drug development [31]. In the present study, anti-arthritic effect of CQME was evaluated in vitro using protein denaturation method. CQME at several concentrations (50 - 
Indo Global Journal of Pharmaceutical Sciences, 2020; 10(1): 50-56

$250 \mu \mathrm{g} / \mathrm{mL}$ ) showed a considerable protection against protein (BSA) denaturation. Both CQME and standard drug showed concentration-dependent inhibition of protein (albumin) denaturation.

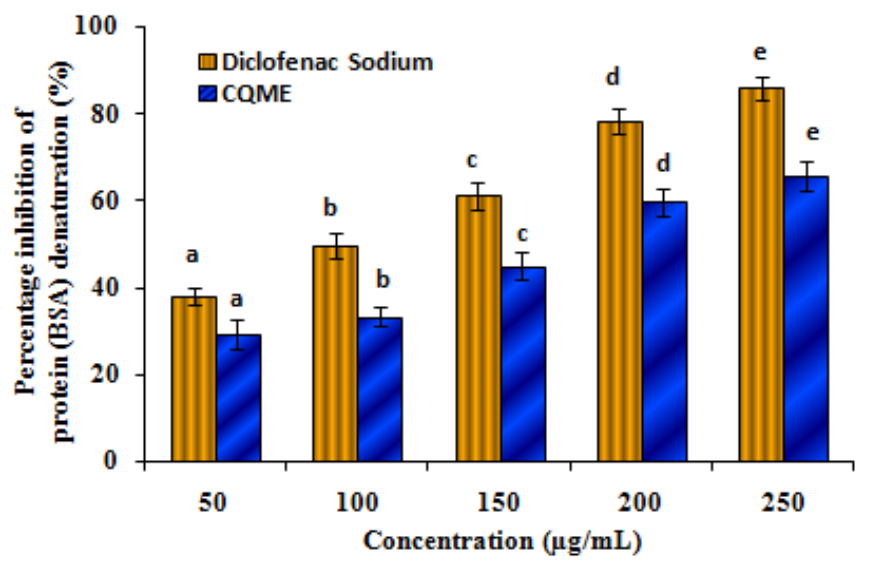

Figure 3. Effect of CQME on percentage inhibition of protein (BSA) denaturation. [CQME = Cissus quadrangularis methanol extract; Values are expressed as mean $\pm S D(n=3)$. Different letters (a-e) indicate a significant difference between the concentrations of the same extract $(P<0.05$, ANOVA, DMRT)].

The anti-arthritic effect of CQME was found to be $29.20 \%$ to $65.74 \%$ at $50-250 \mu \mathrm{g} / \mathrm{mL}$ (Figure 3). There was a significant difference in percentage inhibition of protein (BSA) denaturation between the concentrations tested $(\mathrm{P}<0.05)$. The $\mathrm{IC}_{50}$ value of CQME was found to be $170.78 \mu \mathrm{g} / \mathrm{mL}$ and the $\mathrm{IC}_{50}$ value of diclofenac sodium was found to be $118.26 \mu \mathrm{g}$ $/ \mathrm{mL}$. From the present results it could be concluded that CQME is capable of reducing the auto-antigens production which indirectly reduces the denaturation of protein, and hence prevent arthritis [32].

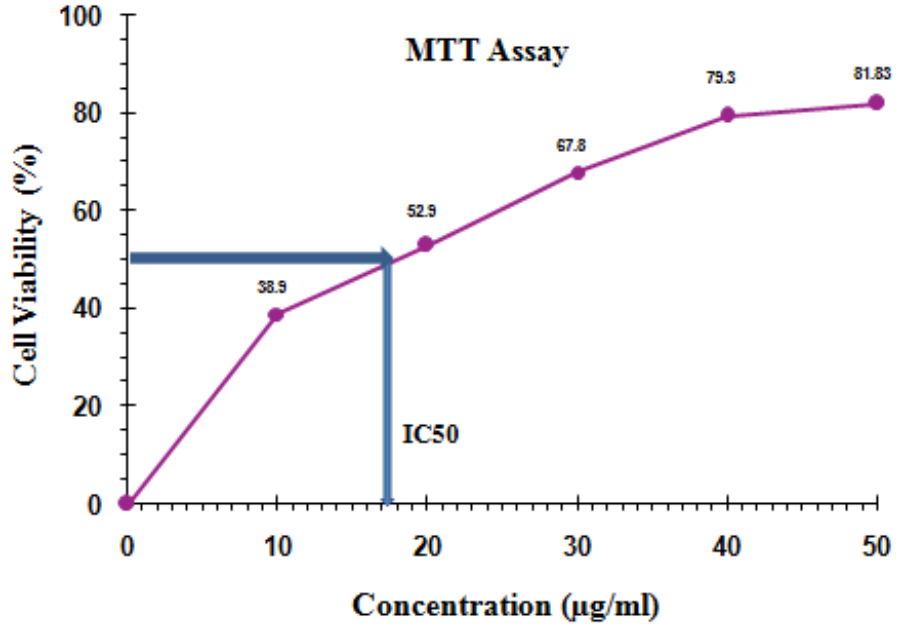

Figure 4: Anticancer effect of CQME on MG63 cell line
Table 1: Preliminary phytochemical analysis of Cissus quadrangularis extracts

\begin{tabular}{|c|c|c|c|c|c|c|}
\hline \multirow{2}{*}{$\begin{array}{l}\text { S. } \\
\text { N } \\
\text { o. }\end{array}$} & \multirow{2}{*}{$\begin{array}{c}\text { Phytoche } \\
\text { mical } \\
\text { compound } \\
\text { S } \\
\end{array}$} & \multicolumn{5}{|c|}{ Extracts } \\
\hline & & $\begin{array}{c}\mathrm{CQE} \\
\mathrm{E}\end{array}$ & $\begin{array}{l}\text { CQ } \\
\text { ME }\end{array}$ & $\begin{array}{c}\text { CQE } \\
\mathbf{A E}\end{array}$ & $\begin{array}{c}\text { CQP } \\
\text { EE }\end{array}$ & $\begin{array}{l}\text { CQ } \\
\mathbf{A E}\end{array}$ \\
\hline 1. & Alkaloids & - & + & + & + & - \\
\hline 2. & $\begin{array}{c}\text { Carbohydra } \\
\text { te }\end{array}$ & - & + & - & - & + \\
\hline 3. & Glycosides & - & - & - & - & - \\
\hline 4. & $\begin{array}{c}\text { Triterpenoi } \\
\text { ds }\end{array}$ & - & + & - & - & - \\
\hline 5. & Steroids & + & + & - & + & - \\
\hline 6. & Saponins & + & + & + & - & + \\
\hline 7. & Proteins & + & + & - & - & + \\
\hline 8. & Phenols & - & + & + & - & + \\
\hline 9. & Flavonoids & + & + & - & + & - \\
\hline
\end{tabular}

(+) Present; (-) Absent; CQEE = C. quadrangularis ethanol extract; $\mathrm{CQME}=C$. quadrangularis methanol extract; $\mathrm{CQEAE}=C$. quadrangularis ethyl acetate extract; $\mathrm{CQPEE}=$ C. quadrangularis petroleum ether extract; $\mathrm{CQAE}=C$. quadrangularis aqueous extract.

Table 2: Total phenol and flavonoid content of CQME.

\begin{tabular}{ccc}
\hline Tomple & $\begin{array}{c}\text { Total Phenols } \\
(\mathrm{mg} \mathrm{FAE} / \mathrm{g})^{\mathrm{A}}\end{array}$ & $\begin{array}{c}\text { Total Flavonoids } \\
(\mathrm{mg} \mathrm{QE} / \mathrm{g})^{\mathrm{B}}\end{array}$ \\
\hline
\end{tabular}

$\begin{array}{lll}\text { CQME } & 14.06 \pm 1.37 & 7.12 \pm 0.91\end{array}$

${ }^{\#}$ Values are expressed as mean $\pm \mathrm{SD}(\mathrm{n}=3)$. CQME $=$ Cissus quadrangularis methanol extract; ${ }^{\mathrm{A}} \mathrm{FAE}=$ ferulic acid equivalents; ${ }^{\mathrm{B}} \mathrm{QE}=$ quercetin equivalents.

In vitro antiproliferative activity of CQME:

In order to evaluate the cytotoxic effect of CQME, a MTT assay with MG63 cell line was performed. MTT assay is a well-established in vitro method for assessing cytotoxicity against cancer cell lines. The extract was screened for its cytotoxicity at different concentrations $(10 \mu \mathrm{g}$ to $50 \mu \mathrm{g})$ to determine the $\mathrm{IC}_{50}$ (50\% growth inhibition) value [33]. When MG63 cells were treated with the CQME, the dead cells were increased by increasing the concentration of CQME from 10 


\section{Indo Global Journal of Pharmaceutical Sciences, 2020; 10(1): 50-56}

to $50 \mu \mathrm{g} / \mathrm{mL}$ (38.90 - 81.83\%). A chart was plotted using the $\%$ cell inhibition in $\mathrm{Y}$ - axis and concentration of CQME in Xaxis. The results are graphically represented in Figure 4. As per ISO 10993:5, CQME showed cytotoxic reactivity to MG63 cells after $24 \mathrm{~h}$ contact. Control gave none cytotoxic reactivity. The $\mathrm{IC}_{50}$ value was found to be $17.5 \mu \mathrm{g} / \mathrm{mL}$ for MG63 cells. According to the National Cancer Institute (NCI), the criteria of cytotoxic activity for the crude extract are $\mathrm{IC}_{50}<$ $20 \mu \mathrm{g} / \mathrm{mL}$ [34]. The $\mathrm{IC}_{50}$ of CQME fall within the NCI criteria, thus it has strong anticancer potential against human osteosarcoma MG63 cells.

\section{CONCLUSION}

In the present study, preliminary phytochemical screening of CQME determined the presence of phenols, carbohydrates, proteins, alkaloids, flavonoids, triterpenoids, saponins and steroids. FT-IR spectrum confirmed the presence of certain bioactive functional groups in CQME. CQME showed strong anti-arthritic activity and also exhibited excellent anticancer activity against human bone cancer cell line, MG63. The potential antioxidant, antiarthritic and antiproliferative potentials may be due to the presence of phytochemicals such as alkaloids, phenols, and flavonoids. In conclusion, the obtained results justify the medicinal and traditional use of Cissus quadrangularis.

\section{ACKNOWLEDGEMENTS}

The authors gratefully acknowledge the authorities and management of PSG College of Arts and Science, Coimbatore, India for providing laboratory facilities.

\section{CONFLICTS OF INTEREST}

There are no conflicts of interest.

\section{DATA AVAILABILITY}

Not declared.

\section{FUNDING AGENCY}

No external funding has been declared.

\section{REFERENCES}

1. Rikke Stamp Thorsen. Traditional medicine for the rich and knowledgeable. Challenging assumptions about treatmentseeking behaviour in rural and peri-urban. Health. Policy. Plann., 2016; 31(3): 314-324.

2. Natori, S., Ikekawa, N., Suzuki, M. Extraction and Isolation of Biologically Active Compounds, Kodansha Ltd, Tokyo112, Japan, Adv. Nat. Prod. Chem., 1981; 275- 287.

3. Chung, K.T., Wong, T.Y., Wei, C.I., Huang, Y.W., Lin, Y. Tannins and human health: a review. Department of Microbiology and Molecular Cell Sciences, University of
Memphis, TN 38152, USA. Crit.Rev.Food. Sci. Nutr., 2010; 38(6): 421-464.

4. Nair, S.S., Kavrekar, V., Mishra, A. Evaluation of in vitro anti diabetic activity of selected plant extracts. Int.J.Pharm.Sci.Invent., 2013; 2(4): 12-19.

5. Ritch-Kro, E.M., Turner, N.J., Towers, G.H. Carrier herbal medicine: an evaluation of the antimicrobial and anti cancer activity in some frequently used remedies. Journal of Ethnopharmacol., 1996; 52(3): 151-156.

6. Austin, D.J, Kristinsson, K.G, Anderson, R.M. The relationship between the volume of antimicrobial consumption in human communities and the frequency of resistance. Proc.Natl. Acad. Sci., 1999; 96(3): 1152.

7. Bhutani, K.K., Kapoor, R., Atal, C.K. Two unsymmetric tetracyclic triterpenoids from Cissus quadrangularis. Phytochem., 1984; 23: 407-410.

8. Shirwaikar, A., Khan, S., Malini, S. Antiosteoporotic effect of ethanol extract of Cissus quadrangularis Linn. on ovariectomized rat. J. Ethnopharmacol., 2003; 89: 245-250.

9. Mallika, J., Shyamala devi, C.S. In vitro and in vivo evaluation of free radical scavenging potential of Cissus quadrangularis. Afr.J.Biomed.Res., 2005; 8: 95-99.

10. Luetke, A., Meyers, P. A., Lewis, I., Juergens, H. Osteosarcoma treatment-where do we stand? A state of the art review. Cancer Treat Rev., 2014; 40(4): 523-532.

11. Janmejai, K.S., Sanjay Gupta. In: Foods and dietary Supplements in the prevention and treatment of disease in older adults. Ch 18.; 2015; 171-183.

12. Edeoga, H.O., Okwu, D.E., Mbaebie, B.O. Phytochemical constituents of some Nigerian medicinal plants. Afr.J. Biotechnol. 2005; 4(7): 685-688.

13. Pustjens, A.M., Schols H. A., Kabel M. A., Gruppen H. Characterisation of cell wall polysaccharides from rape seed (Brassica napus) meal. Carbohydr.Polym., 2013; 98, 16501656.

14. Singleton VL, Rossi JA. Colorimetry of total phenolics with phosphomolybdic-phosphotungstic acid reagents. Am. J. Enol. Viticult., 1965; 16: 44-158.

15. Jia $\mathrm{Z}$, Tang $\mathrm{M}, \mathrm{Wu} \mathrm{J}$. The determination of flavonoid contents in mulberry and their scavenging effects on superoxide radicals. Food. Chem., 1999; 64: 555-599.

16. Ruch RJ, Chug SU, Klaunig JE. Spin trapping of superoxide and hydroxyl radicals. Met. Enzymol., 1984; 105: 198-209.

17. Sheelarani T, Gopal V, Seethalakshmi S, Chitra K. In vitro anti-inflammatory and anti-arthritic activity of selected medicinal plant. Int. J. Pharm. Sci. Rev. Res., 2014; 28: 162163.

18. Janki, B.P. An in vitro anticancer activity of aqueous extract of Triticum aestivum on hep2 human epithelioma of larynx cell line. World. J. Pharm. Pharm. Sci., 2016; 5(6): 15201530 .

19. Kanetkar, P.V, Singhal, R.S., Laddha, K.S., Kamat, M.Y. Extraction and quantification of gymnemic acids through gymnemagenin from callus cultures of Gymnema sylverstre. Phytochem. Anal., 2006; 17(6): 409-413.

20. Parimala Devi, B., Ramasubramaniaraja, R Pharmacognostical and antimicrobial screening of Gymnema sylvestre $\mathrm{R} . \mathrm{Br}$, and evaluation of Gurmar herbal tooth paste and powder, composed of Gymnema sylvestre $\mathrm{R} . \mathrm{Br}$, extracts in dental caries. Int. J. Pharm. Bio Sci., 2010; 1(3): 1.

21. Mungole, A.J., Awati, R., Chaturvedi, A., Zanwar, P. Preliminary phytochemical screening of Ipomoea obscura (L) -A hepatoprotective medicinal plant. Int. J. Pharm. Tech. Res., 2010; 2: 2307-2312. 
Indo Global Journal of Pharmaceutical Sciences, 2020; 10(1): 50-56

22. Renuka, B., Sanjeev, B., Ranganathan, D. Evaluation of phytoconstituents of Caralluma nilagirina by FT-IR and UVVis spectroscopic analysis. J. Pharmacog. Phytochem., 2016; 5(2): 105-108.

23. Ragavendran, P., Sophia, D., Arul Raj, C., Gopalakrishnan V.K. Functional group analysis of various extracts of Aerva lanata (L.,) by FTIR spectrum. Pharmacologyonline., 2011; 1: 358-364.

24. Parag, A., Pednekar, B.R. Antimicrobial and antioxidant potential with FT-IR analysis of Ampelocissus latifolia (roxb.) Planch leaves. Asian. J. Pharm. Clin. Res., 2013; 6(1): 67-73.

25. Kähkönen, M.P. et al. Antioxidant activity of plant extracts containing phenolic compounds. J. Agr. Food. Chem., 1999; 47: 3954-62.

26. Liu, R.H. Potential synergy of phytochemicals in cancer prevention: Mechanism of action. J. Nutr., 2004; 134: 3479S-85S.

27. Finimundy, T.C. et al. Aqueous extracts of Lentinula edodes and Pleurotus sajor-caju exhibit high antioxidant capability and promising in vitro antitumor activity. Nutr. Res., 2013; 33: 76-84.

28. Re, R., Pellegrini, N., Proteggente, A., Pannala, A., Yang, M., Rice-Evans, C. Antioxidant activity applying an improved ABTS radical cation decolorization assay. Free Rad. Biol. Med., 1999; 26: 1231-7.

29. Sahreen, S., Khan, M.R., Khan, R.A. Phenolic compounds and antioxidant activities of Rumex hastatus D. Don. Leaves. J. Med. Plant. Res., 2011; 5: 2755-65.

30. Vane, J.R. and Botting, R.M. New insights into the mode of action of anti-inflammtory drug. Inflam. Res., 1995; 44: 110.

31. Chandra, S., Chatterjee, P., Dey, P., Bhattacharya, S. Evaluation of in vitro anti-inflammatory activity of coffee against the denaturation of protein. Asian. Pac. J. Trop. Bio., 2012; 2: S178-S180.

32. Grant, N.H., Alburn, H.E., Kryzanauskas, C. Stabilization of serum albumin by anti-inflammatory drugs. Biochem. Pharmacol., 1970; 19: 715-722.

33. Singh, K., Deo, B. Phytochemical evaluation and in vitro antioxidant activity of Gymnema sylvestre R.Br. J. Med. Plant. Stud., 2014; 2(4): 19-23.

34. Boik, J. Natural Compounds in Cancer Therapy, Oregon Medical Press, Minnesota, Minn, USA. Pharm. Biol., 2001; 40(1): 79-79. 